\title{
Análise Comparativa da Avaliação Funcional Realizada na Lesão Medular em Animais.
}

\author{
Comparative Analysis of Functional Evaluation performed in medullary injury in animals.
}

\section{Alessandra Iague Molina ${ }^{1}$, Alexandre Fogaça Cristante 2 , Tarcísio Eloy Pessoa de Barros Fillo ${ }^{3}$}

\section{RESUMO}

A avaliação comportamental após, a contusão da medula espinhal, enfocou por um tempo a locomoção em campo aberto usando uma escala de classificação desenvolvida por Tarlov et al. ${ }^{(18)}$. Tarlov ${ }^{(17)}$ realizou estudos experimentais em cães, produzindo compressão medular com atribuição de zero a cinco para graduação dos movimentos do animal. Contudo, esta escala tem sido modificada por pesquisadores e suas alterações feitas por vários grupos tornaram as comparações das medidas do resultado locomotor difíceis. Um aspecto crítico da pesquisa utilizando lesão medular em animais é a padronização da avaliação da recuperação locomotora. A escala desenvolvida por Tator ${ }^{(19)}$ é simples e de fácil utilização, porém pode não analisar todos os aspectos necessários

Basso, Beattie e Bresnahan ${ }^{(2,3)}$ apresentaram uma escala de classificação com índice de recuperação locomotora em ratos que sofreram lesão medular produzida em laboratório. Os dados indicam que a escala BBB é uma medida válida para a recuperação locomotora capaz de distinguir os resultados comportamentais em função de ferimentos diferentes e para prever alterações anatômicas no centro da lesão.

O propósito deste estudo foi analisar e comparar escalas de classificação locomotora sem ambigüidade, eficientes e expandida para se padronizar as medidas resultantes nos laboratórios.

Descritores: Lesão experimental da medula espinhal; Recuperação motora; Trauma.

\section{INTRODUÇÃO}

Uma avaliação do comportamento após o ferimento da medula espinhal é necessária, pois determina a eficácia terapêutica. Medidas resultantes comportamentais bem definidas podem também

Trabalho realizado pelo Departamento de Ortopedia e Traumatologia da Faculdade de Medicina da Universidade de São Paulo, integrante do projeto de Dissertação para obtenção do título de Mestre . Estudo desenvolvido no Instituto de Ortopedia e Traumatologia da Faculdade de Medicina da Universidade de São Paulo.

1 - Pós-graduanda do Departamento de Ortopedia da Faculdade de Medicina da USP

2 - Médico Preceptor do Instituto de Ortopedia e Traumatologia do HC FMUSP.

3 - Professor Titular do Departamento de Ortopedia e Traumatologia da Faculdade de Medicina da USP.

Endereço para correspondência: Av. São Paulo 154,

Mogi das Cruzes, S.P. - CEP 08780570 - (11)47982522

E-mail:sac@clinicasaopaulo.com.br

\section{SUMMARY}

The behavior evaluation after a spinal medulla injury focused the locomotion in field during a certain time, using a classification scale developed by Tarlov et al. ${ }^{(18)}$. Tarlov ${ }^{(17)}$ performed experimental studies in dogs, producing medullary compression and assigning a graduation from zero to five to the animal movements. However, this scale has been changed by researchers and its changes, made by several groups, became difficult the comparisons of the measures of the locomotor result. One critical aspect of the research with medullary injury in animals is the standardization of the locomotor recovery evaluation. The scale developed by Tator(19) is simple and easy to use but it can't analyze all the necessary aspects.

Basso, Beattie e Bresnahan ${ }^{(2,3)}$ showed a classification scale with a locomotor recovery level in rats presenting a medullary injury produced in laboratory. The data show that the BBB scale is a valid measure to the locomotor recovery and it makes it possible to distinguish the behavior responses in function of the different wounds and to antecipate the anatomical changes in the center of the injury.

The purpose of the study was the analysis and comparison of locomotor classification scales, without ambiguity, efficient and expanded in order to standardize the final measures in laboratories.

Key words: Spinal medulla experimental injury, Motor recovery, Trauma

\section{INTRODUCTION}

An evaluation of the behavior after the spinal medulla injury is necessary to determine the therapeutical effectiveness. The resulting welldefined behavior measures can also identify the potential mechanisms of functional recovery. Several researchers developed tests in order to
Work performed by the Orthopedics and Traumatology Department of São Paulo University Medical School - part of the thesis project to obtain the Master degree.

1 - Postgraduate student of São Paulo University - Medical School

2 - Doctor Preceptor of the Orthopedics and Traumatology Department at the General Hospital of the São Paulo University - Medical School

3 - Chairman of Orthopedics and Traumatology Institute at the General Hospital of São Paulo University-Medical School

Adress: Av. São Paulo 154,

Mogi das Cruzes, S.P. CEP 08780570 - (11) 47982522

E-mail:sac@clinicasaopaulo.com.br 
identificar os mecanismos potenciais de recuperação funcional. Vários investigadores desenvolveram testes para medir a função do reflexo sensorial e locomotor na lesão medular em animais. Tais resultados variaram desde simples descrições qualitativas do ato de andar até a elaboração de combinações de testes com a intenção de detectar manifestações diversas no funcionamento SNC (Sistema Nervoso Central).

Não se chega normalmente a um acordo sobre qual tipo de ferramenta de avaliação comportamental é a mais útil ou importante para descrever a recuperação funcional. A sensibilidade dos testes elaborados pode torná-los mais adequado para investigações detaIhadas dos mecanismos de recuperação, mas geralmente impraticáveis para uso em testes pré-clínicos. Embora sejam simples de usar, normalmente têm sensibilidade muito limitada em função da confiança no que diz respeito a suas observações subjetivas. No uso de testes pré-clínicos, a ferramenta de avaliação ideal seria aquela que é de fácil utilização, sensível à detalhes pequenos e capaz de rapidamente avaliar de forma geral a função locomotora em um grande número de animais nas experiências. Allen ${ }^{(1)}$ desenvolveu um modelo experimental para produzir lesão medular e qualificou a lesão como o produto peso em grama pela altura em centímetros (g/ $\mathrm{cm}$ ). Tarlov ${ }^{(17)}$ e Tarlov et al. ${ }^{(18)}$ realizaram um estudo experimental em cães produzindo compressão medular e apresentou um método de avaliação locomotora.

Ford ${ }^{(12)}$ modificou o método de lesão por Allen e realizou lesão medular em gatos.

Wrathall et al.(22) propuseram um protocolo para avaliar o déficit funcional que ocorria após lesão medular produzida em ratos uma vez que a escala de Tarlov não foi reprodutível com confiabilidade em outros laboratórios. Os resultados indicaram diferetes graus de lesão, podendo classifica-las em leve, moderada e grave.

Noble e Wrathall(16) promoveram lesão medular graduada em ratos e utilizaram uma escala de avaliação da função motora que foi modificação do teste de Tarlov.

Basso et al. ${ }^{(2)}$ afirmou que os estudos da recuperação locomotora em ratos que sofreram lesão medular haviam seguido modificações da escala de Tarlov.

Alguns autores afirmam que o que chega mais próximo do ideal são as escalas qualitativas ou semiquantitativas, como por exemplo aquelas originalmente concebidas por Tarlov et al. ${ }^{(18)}$, e posteriormente modificadas por outros investigadores.

O presente estudo compara uma escala de avaliação motora para lesão medular experimental como a escala modificada de Tarlov, que se correlaciona com o resultado anatômico e com a descrição física do ferimento nos animais (ex: deslocamento, força, impulso momentâneo) à escala qualitativa apresentada por Basso et al.(2) objetivando avaliar sua sensibilidade e aplicabilidade.

Alguns problemas percebidos podem ser resultado da falha da escala de Tarlov em refletir sobre o processo de recuperação funcional em andamento de maneira mais segura, a escolha de definições operacionais dos elementos locomotores deveriam também facilitar a transferência de dados precisos entre laboratórios.

Assim sendo, analisamos estas escalas procurando confrontar dados para se obter uma escala de maior sensibilidade e confiança na avaliação locomotora da lesão medular em animais.

\section{MATERIAL E MÉTODOS Metodologia}

A metodologia utilizada foi a revisão da literatura tendo como fonte utilizada a Bireme, na qual foram consultados os banco de dados da Medline, Lilacs e artigos em revistas. Foram consultadas as bibliotecas do Instituto de Ortopedia e do Instituto de Neurologia da Facul- measure the locomotor and sensorial reflection function in the medullary injury in animals. Such results varied from the simple qualitative descriptions of walking to the elaboration of test combinations intending to detect many demonstrations in CNS (Central Nervous System) function.

Normally, there isn't and agreement about which type of behavior evaluation tool is the most useful or important to describe the functional recovery.

The sensibility of elaborated tests can make them more adequate to detailed investigations of the recovery mechanisms, but in general impracticable for use in pre-clinical tests. Although they are simple to apply, they normally present a limited sensibility because of the reliability regarding the subjective observations. In pre-clinical test use, the ideal evaluation tool would be easy to use, sensible for small details and able to evaluate rapidly in a general way, the motor function in a great number of animals in the experiences.

Allen(1) developed an experimental model to produce medullary injury and qualified the injury as a product weight in gram by the height in centimeters $(\mathrm{g} / \mathrm{cm})$. Tarlov ${ }^{(17)}$ and Tarlov et al. ${ }^{(18)}$ performed an experimental study in dogs producing medullary compression and presented a locomotor evaluation method.

Ford ${ }^{(12)}$ modified the injury method by Allen and performed medullary injury in cats. Wrathall et al.(22) purposed a protocol to evaluate the functional deficit after a medullary injury produced in rats, as the Tarlov scale wasn't reproduced in a reliable way in other laboratories. The results showed different injury degrees, permitting the classification in light, moderate and severe.

Noble e Wrathal/(16) promoted a graduated medullary injury in rats and used one evaluation scale of motor function that was a change of the Tarlov's test.

Basso et al.(2) assured that the locomotor recovery studies in rats that presented a medullary injury had followed changes in Tarlov's scale. Some authors assure that the closest to the ideal are the qualitative and semi-qualitative scales, as those ones originally developed by Tarlov et al. ${ }^{(18)}$, and posterior modified by other investigators, for example.

The present study compares a motor evaluation scale for experimental medullary injury as the modified Tarlov's scale that is correlated to the anatomical result and to the physical description of the wound in animals (e.g.: displacement, force, transitory impulse) to the qualitative scale presented by Basso et al. ${ }^{(2)}$ aiming to evaluate its sensibility and appliance.

Some observed problems could be a result from the failure in Tarlov's scale in reflecting the functional recovery process in progress in a safer way. The choice of working definitions of locomotor elements should also facilitate the transfer of accurate data among laboratories.

This way, we analyzed these scales trying to compare data in order to obtain a more sensitive and trustful scale in locomotor evaluation of medullary injury in animals.

\section{MATERIAL AND METHODS}

\section{Methodology}

The applied methodology was the literature review using Bireme source, and the data banks of Medline, Lilacs besides magazines articles. The libraries of the Orthopedics Institute and the Neurology Institute of São Paulo University - Medical School were consulted as well as the library of the Instituto do Coração. 
dade de Medicina da Universidade de São Paulo assim como a biblioteca do Instituto do Coração.

\section{Amostragem da Escala BBB}

Um total de 85 ratos fêmeas (250-300g) sustentaram contusões medulares e foram usados para desenvolver ou validar a escala BBB. Alguns ratos foram usados para o desenvolvimento e validação da escala, enquanto outros foram usados exclusivamente para fins de validação; dos 11 ratos com contusões OSU leves, 6 foram usados tanto para desenvolvimento como para validação (parâmetros de severidade). Os 5 ratos restantes foram apenas usados para validação ( parâmetros de severidade, anatomia e variação). Um rato SpragueDawley foi sacrificado durante a semana pós-operatória em função de anatomia, e um rato Long-Evans morreu de causas desconhecidas durante $11^{\circ}$ semana pós-operatória.

\section{Procedimentos Cirúrgicos}

Todos os ratos foram submetidos a procedimentos cirúrgicos na Universidade Estadual de Ohio (OSU) . Rapidamente, os ratos foram anestesiados com cetamina $(80 \mathrm{mg} / \mathrm{kg})$ e xilazina $(10 \mathrm{mg} / \mathrm{kg})$ e a esses foram dados antibióticos profiláticos (sulfato gentomicina 1mg/ $\mathrm{kg})$.

Após uma exposição de laminectomia médio torácico, nível de segmento do cordão T7, T8 ou T9, os ratos foram contundidos com o impactor OSU ou com impactor da Universidade de Nova York(NYU). Os grupos foram mencionados como OSU leves, OSU moderados, NYU leves, e NYU moderados. O Impactor NYU é um dispositivo eletromagnético que cria uma contusão através do deslocamento da superfície da medula a uma distância especifica. No presente estudo a medula espinhal foi deslocada 0,8 ou 0,9 mm para contusões leves e 1,1 mm para contusões moderadas.

O Impactor NYU é um dispositivo com peso que libera uma haste de 10-g a partir de várias alturas sobre a medula exposta. Os movimentos da haste de impacto e a coluna vertebral são registrados usando potenciômetros óticos. Para o presente estudo, a haste foi derrubada de alturas de $6,25 \mathrm{~mm}$ para contusões leves e $12,5 \mathrm{~mm}$ e $25 \mathrm{~mm}$ para contusões moderadas. Dois ratos caíram dos grampos espinhais sob o impacto de alturas de 12,5 ou $25 \mathrm{~mm}$, e Impactor atingiu o osso ao invés da dura mater, outro rato sofreu contusão a partir de $12,5 \mathrm{~mm}$ de altura. Dessa forma, esses ratos sustentaram uma força de contusão menor no impacto e foram incluídos na categoria leve ao invés da categoria moderada.

\section{Procedimentos Apresentados}

Três ambientes de campo aberto foram usados nesse estudo: um enclausuramento em metal circular $(106,7 \mathrm{~cm}$ de diâmetro, $61 \mathrm{~cm}$ de altura), uma piscina de plástico moldada com ranhuras no piso (100cm de diâmetro, $21 \mathrm{~cm}$ de altura), e uma piscina de plástico menor com piso liso $(90 \mathrm{~cm}$ de diâmetro, $7 \mathrm{~cm}$ de altura). Os ratos foram expostos ao ambiente de teste diariamente por pelo menos 10 dias ou duas vezes ao dia por pelo menos 5 dias, com a maior parte das sessões ocorrendo consecutivamente. Vários ratos foram colocados uma vez em campo aberto durante cada sessão de 30/60min., para que assim se acostumassem a serem pegos e movimentados enquanto estivessem em campo aberto. As sessões de pré-teste foram continuas até que os ratos não apresentassem mais sinais de medo (fugindo do examinador, pouca ou nenhuma locomoção, urina e fezes freqüentes, vocalizações ereção dos pêlos).

\section{Procedimentos de Testes}

Dois examinadores participaram de todos os testes de campo aberto e ficaram posicionados transversalmente para observar os dois

\section{BBB scale sample}

A total of 85 female rats (250-300 g) presented medullary contusion and was used to develop or validate the BBB scale. Some rats were used to develop and validate the scale, while other were exclusively used to validation; from the 11 rats presenting light OSU contusions, 6 were used to development and to validation (parameters of severity). The 5-resting rats were only used to validation (parameters of severity, anatomy and change). One Sprague-Dawley rat was killed during the postoperative week in function of the anatomy and a LongEvans rat died of unknown causes during the eleventh postoperative week.

\section{Surgical Procedures}

All the rats underwent surgical procedures in the Ohio State University (OSU). Rapidly, the rats were anesthetized with ketamine (80 $\mathrm{mg} / \mathrm{kg})$ and xylazine $(10 \mathrm{mg} / \mathrm{kg})$ and these ones received prophylactic antibiotics (gentamicin sulfate $1 \mathrm{mg} / \mathrm{kg}$ ).

After a medius thoracic laminectomy exposure, segment level of cord T7, T8 or T9, the rats were bruised with OSU Impactor or with the New York University (NYU) Impactor. The groups were mentioned as OSU light, OSU moderate, NYU light and NYU moderate. The NYU Impactor is an electromagnetic device that produces a contusion by displacing the surface of the medulla from a particular distance. In the present study, the spinal medulla was displaced 0,8 or $00,9 \mathrm{~mm}$ to produce light contusions and 1,1 $\mathrm{mm}$ to moderate contusions.

The NYU Impactor is a device with weight that discharges a nail of $10 \mathrm{~g}$ from several heights on the open medulla. The movements of the impact nail and the spinal cord are registered by otic potentiometers. For the present study, the nail was dropped from 6,25-mm height for light contusions and from $12,5 \mathrm{~mm}$ and $25 \mathrm{~mm}$ for moderate contusions. Two rats fell from the spinal tongs with the impact of 12,5 or 25 $\mathrm{mm}$ height and the Impactor hit the bone instead of the dura mater; other rat presented contusion from 12,5 $\mathrm{mm}$ height. This way, these rats maintained a shorter contusion force in impact and were included in the light category instead of the moderate one.

\section{Presented procedures}

Three ambience of field were used in this study: an enclosure in circular metal (106,7 cm of diameter and $61 \mathrm{~cm}$ of height), a plastic pool modeled with grooves on the floor $(100 \mathrm{~cm}$ of diameter and 21 $\mathrm{cm}$ of height) and a smaller plastic pool with plain floor. $(90 \mathrm{~cm}$ of diameter and $7 \mathrm{~cm}$ of height). The rats were exposed to the test ambient diary during at least 10 days or twice a day for at least 5 days. Most of the sessions occurred consecutively. Several rats were placed in field once during each 30/60-minute session in order to get used to the movement while they were in field. The pre-tests sessions were continuous until the rats didn't show any sign of fear (running from the examiner, little or no locomotion, frequent urine and feces, vocalization, hair erection).

\section{Tests procedures}

Two examiners participate of all field tests and were positioned transversally in order to observe the two sides of the rat. The rats were tested alone for 4 minutes or in pairs for 5 minutes. The experience showed that the 4-minute sessions provide enough time to observe and register the recovery in individual rats with minimum risk of losing key finds. The rats were individually evaluated during the reliability tests among the classifications and the validation of the scale. 
lados do rato. Os ratos foram testados sozinhos por $4 \mathrm{~min}$. e ou em pares por $5 \mathrm{~min}$. A experiência indicou que as sessões de $4 \mathrm{~min}$. forneciam tempo suficiente para observar e registrar a recuperação de ratos individuais com risco mínimo de perder descobertas chaves. Os ratos foram avaliados individualmente durante os testes de confiabilidade entre as classificações e a validação da escala.

Durante os teste de campo aberto, os ratos foram estimulados a se locomover continuamente. Os ratos que permaneceram parados por mais de 15/20seg. foram provocados a se movimentar através de um lápis ou um pedaço de papel que eles tinham que seguir, ou através de tapas ou arranhões leves. Caso o animal falhasse ao responder a esses estímulos, eles eram pegos e colocados no centro do campo aberto, o que normalmente os forçava a se movimentar para as laterais. Foi tomado cuidado especial evitando tocar o rabo e/ou a parte traseira durantes os teste pois este estímulo parecia afetar o desempenho motor. Nos testes que avaliavam pares de ratos, os períodos de observação foram às vezes estendidos além de $5 \mathrm{~min}$. para a obtenção de avaliações mais precisas sobre a liberação dos dedos, posicionamento das patas, ou coordenação dos membros frontais e traseiros. Em casos de desempenho locomotor limítrofe ou diferenças entres os examinadores, os resultados indicando maiores déficits foram adotados. Todos os movimentos dos membros traseiros foram registrados exceto aqueles que eram obviamente parte de um reflexo ou selecionados pelo toque de um examinador ou outro animal. Por exemplo, um único reflexo visto logo após a contusão, porém não registrado como componente locomotor foi diminuído pela espinha lombar, enrolamento do rabo, e flexão bilateral extensiva das juntas dos quadris, joelhos, e do calcanhar. Esse reflexo pode ter resultado do estimulo perineal quando o rato se jogava para frente com os membros frontais

\section{Avaliação Funcional Escala Basso, Beatie and Bresnahan (B.B.B.)}

A escala BBB observa os movimentos da articulação do quadril, joelho, tornozelo, posição do tronco, rabo e patas traseiras. A partir destas observações, foram atribuídos pontos de zero a 21, sendo zero o correspondente à ausência total de movimentos e 21 à presença de movimentos normais .

0 - não observação de movimento nos membros posteriores(MP)

1 - suave movimento de uma ou duas articulações, normalmente o quadril e/ou joelho.

2 - extenso movimento de uma articulação ou extenso movimento de uma articulação e suave movimento de uma outra articulação

3 - extenso movimento de duas articulações do MP

4 - suave movimento de mais de três articulações MP

5 - suave movimento de duas articulações e extenso movimento de uma terceira

6 - extenso movimento de duas articulações e suave movimento de uma terceira

extenso movimento em todas as três articulações do MP

7 - largo movimento com nenhum peso de suporte ou colocação plantar da pata com nenhum peso de suporte

8 - colocação plantar da pata com peso suporte em postura ( quando parado) ou ocasional, freqüente, ou consistente suporte de peso na passada dorsal e nenhum apoio na passada plantar , movimentos suaves sem suportar o peso do corpo .

9 - ocasional suporte de peso na passada plantar, nenhum MSMP coordenação

10 - freqüência constante do suporte de peso na passada plantar, nenhuma MS-MP coordenação

11 - freqüência constante do suporte de peso na passada plan-
During the field tests, the rats were stimulated to move continuously. The rats that stopped during more than 15/20 seconds were incited to move by a pencil, a piece of paper that they should follow

or by slaps or light scratches. If the animal failed in responding to these stimuli, they were caught and placed in the center of the field, what normally forced them to move to the sides. It was taken a special care, avoiding touching the nail and/or the back during the tests because this stimulus appeared to affect the motor performance. In the tests that evaluated pairs of rats, the observation periods lasted more than five minutes to obtain more accurate evaluations on the discharge of toes, feet position or coordination of frontal and posterior members.

In cases where the locomotor performance was limitrophe or in those where there were differences among the examiners, the results that showed the highest deficits were adopted. All posterior members movements were registered except those that obviously were part of a reflection or selected by an examiner or other animal touch. For example, one single reflection observed right after the contusion, therefore not registered as a locomotor component was diminished by the lumbar spine, nail twisting and extensive bilateral flexion of the hip, knee and heel together. This reflection can be a response of the perineal stimulus when the rat threw itself ahead using the frontal members.

\section{Functional Evaluation - Basso, Beatie and Bresnahan (B.B.B.)} scale

The BBB scale observes the articulation movements of the hip, knee and ankle, besides the trunk, tail and posterior feet position. From these observations, points from zero to 21 were attributed. The zero corresponded to the total lack of movements and the 21 to the normal presence of movements.

\section{0 - non-observation of movement in posterior members (PM)}

1 - soft movement of one or two articulations, normally the hip and/or the knee.

2 - extensive movement of an articulation or extensive movement of an articulation and soft movement of another articulation

3 - extensive movement of two articulations of PM

4 - soft movement of more than three articulations PM

5 - soft movement of two articulations and extensive movement of a third one

6 - extensive movement of two articulations and soft movement of a third one - extensive movement of all the three articulations of PM

7 - wide movement without a support weight or plantar placement of the foot without a support weight.

8 - plantar placement of the foot with a support weight in posture (when stopped) or occasional, frequent or consistent weight support in the dorsal step and no support in plantar step, soft movements without supporting the body weight.

9 - occasional weight support in the plantar step, no SM-PM coordination

10 - constant frequency of weight support in plantar step, no SMPM coordination

11 - constant frequency of weight support in plantar step and occasional SM of coordination

12 - constant frequency of weight support in the plantar step and frequent SM-PM of coordination 
tar e ocasional MS de coordenação

12 - freqüência constante do suporte de peso na passada plantar e freqüente MS-MP de coordenação

13 - constante suporte de peso na passada plantar ,constante MS-MP de coordenação;

14 - constante passada plantar e constante MS-MP com coordenação e predominância da posição das patas em rotação (interna ou externa) quando começa o contato inicial com a superfície antes mesmo de levantar no fim da postura ou freqüente passada plantar, constante MS-MP com coordenação e ocasional passada dorsal

15 - constante passada plantar constante MS-MP coordenados ; e nenhum movimento do dedos dos pés ou ocasional movimento dos dedos dos pés durante o avanço do membro seguinte

Predominante posição da pata, paralela ao corpo no contato inicial

16 - constante passada plantar e constante coordenação MS-MP durante $\mathrm{o}$ andar ;e dedos dos pés livres ocorrem freqüentemente durante $\mathrm{o}$ avançar dos membros dianteiros

predominantemente a posição das patas estão paralelas no contato inicial e rodados ao se levantar.

17 - constante passada plantar e constante coordenação MSMP durante o andar; e os dedos dos pés livres ocorrem freqüentemente durante o avançar dos membros dianteiros predominantemente a posição das patas estão paralelas no contato inicial e ao levantarse.

18 - constante passada plantar e constante coordenação MSMP durante o andar, os dedos dos pés livres ocorrem constantemente durante o avançar dos membros dianteiros predominantemente a posição das patas estão paralelas no contato inicial e rodadas ao levantar-se.

19 - constante passada plantar e constante coordenação MSMP durante o andar, os dedos dos pés livres ocorrem constantemente durante o avançar dos membros dianteiros predominantemente a posição das patas estão paralelas no contato inicial e ao levantar-se; o rabo mantém-se para baixo todo o tempo ou apenas parte dele.

20 - constante passada plantar e constante coordenação ao andar, constantes movimentos livres dos dedos dos pés ; predominantemente a posição das patas estão paralelas no contato inicial e ao levantar se ;e instabilidade do tronco ;rabo constantemente para cima.

21 - constante passada plantar e andar coordenado, constantes movimentos livres dos pés, posição das patas predominantemente paralelas durante a postura, constante estabilidade de tronco, rabo constantemente para cima.

\section{Desenvolvimento da Escala}

Para desenvolver a escala, documentou-se os padrões de movimento apresentados pelos ratos durante a recuperação. Os grupos, leves e moderados, foram testados em pares por períodos de $5 \mathrm{~min}$.; 42 ratos usados para o desenvolvimento da escala fizeram parte de um outro estudo e foram monitorados semanalmente. Um checklist preliminar de vários padrões motores foi formulado a partir do conhecimento sobre recuperação locomotora e da escala de classificação prévia. Categorias comportamentais adicionais foram incluídas neste checklist ao passo que se tornaram mais aparentes. Essas categorias serviram de base para a escala BBB.

Um formulário de classificação foi feito para acompanhar a escala BBB e fornecer uma descrição rápida e precisa do desempenho locomotor, que poderia ser facilmente traduzido em resultado locomotor. O formulário de classificação foi organizado em três sessões amplas representando as fases iniciais, intermediária e avançada da recuperação. O examinador se movimentou da esquerda para a di-
13 - constant weight support in the plantar step, constant SM-PM of coordination

14 - constant plantar step and constant SM-PM with coordination and predominance of feet position in rotation (internal or external) when the initial contact with the surface starts before getting up at the end of the posture or frequent plantar step, constant SM-PM with coordination and occasional dorsal step

15 - constant plantar step constant SM-PM coordinate, no movement of toes or occasional movement of toes during the advance of the following member.

Predominant position of the foot, paralle/ with the body at the first contact

16 - constant plantar step and constant SM-PM coordination during the walk and free toes. This frequently occurs during the anterior members advance. Predominantly, the feet are parallel at the first contact and rotated when getting up.

17 - constant plantar step and constant SM-PM coordination during the walk, free toes. It frequently occurs during the anterior members advance. feet predominantly in parallel at the first contact and when getting up.

18 - constant plantar step and constant SM-PM coordination during the walk, free toes. It constantly occurs during anterior members advance. feet position predominantly in parallel at the first contact $e$ rotated when getting up.

19 - constant plantar step and constant SM-PM coordination during the walk, free toes. It constantly occurs during the anterior members advance. feet position predominantly in parallel at the first contact and when getting up; the tail remains turned down all the time or almost all te the time.

20 - constant plantar step and constant coordination during the walk, constant free movements of toes, feet position predominantly in parallel at the first contact and when getting up; instability of trunk, nail constantly turned up.

21 - constant plantar step and coordinate walk, constant free movements of feet, feet position predominantly in parallel during the posture, constant trunk stability, tail constantly turned up.

\section{Scale development}

To develop the scale, the movement standards the rats presented during the recovery were registered. The soft and moderate groups were tested in pairs for 5 minutes; 42 rats used to develop the scale took part of another study and were verified weekly. One preliminary checklist of several motor standards was elaborated from the knowledge about locomotor recovery and the previous classification scale.

Additional behavior categories were included in this checklist and they became clearer. These categories were the basis to the BBB scale. One classification form was produced in order to attend the BBB scale and provide a fast and accurate description of the locomotor performance, what could be easily translated into a locomotor result. The classification form was organized in three wide sessions representing the initial, intermediate and advanced stages of recovery.

In this form, the examiner moved from left to right while the rats were recovery. This strategy was developed in order to help the examiners to antecipate the behavior categories, understand their observations and avoid losing the transitions from one category to other. The function of each posterior member (right and left) was observed and registered. 
reita nesse formulário ao passo que os ratos se recuperavam. Essa estratégia foi desenvolvida para ajudar os examinadores a antecipar as categorias comportamentais, visualizar suas observações e evitar perder as transições de uma categoria para a outra. A função em cada membro traseiro (direito e esquerdo) foi observada e documentada.

\section{Validação da Escala}

Avaliou-se a eficácia da escala BBB através da analise da relação entre os resultados locomotores e o tamanho da lesão, sensibilidade a contusões severas diferentes e a variação dos resultados entre categorias. Para validar a nova escala comparou-se os resultados dos ratos com ferimentos de diferentes gravidades em dois grupos. Se a escala fosse válida, deveria distinguir os ratos machucados com contusões leves e moderadas.

A relação entre tamanho da lesão e resultados finais de campo aberto foram analisados em um sub-conjunto de ratos machucados. Os cordões incluídos na analise representaram todos os ratos desse estudo. Alguns animais foram excluídos da analise anatômica em função de morte prematura, perda de tecido, investigações anatômicas de invasão mais profunda ou forma disforme do cordão na área da lesão.

A variação entre classificadores foi testada em 6 classificadores que tinham experiência de classificação em campo aberto entre mínima até extensiva antes do treinamento com a escala BBB. A variação entre classificadores foi medida duas vezes: uma vez após os examinadores terem completado 49 testes de campo aberto com a escala BBB e novamente após terem registrado 118 testes. Durante cada sessão, animais representando as fases iniciais, intermediária e avançada da recuperação foram testados. Durante as sessões de testes entre classificadores, os investigadores individuais registraram os resultados com os ratos primeiro de maneira independente, e depois formaram duplas para discutir e definir um consenso sobre os resultados. Assim, cada animal recebeu 6 notas individuais e 3 notas de equipe.

\section{Confiabilidade entre Classificadores}

Para avaliar a confiabilidade da escala de classificação, comparou-se os resultados elaborados por 6 examinadores com os mesmos ratos. A variação entre classificadores foi estimada a partir do desvio padrão dos resultados apresentados pelos examinadores. A variação foi notoriamente baixa, tanto para as modalidades individuais quanto para equipes. O resultado médio de variação para os 6 indivíduos estava dentro dos limites da categoria de resultado para cada uma das sessões (sessão 1: $\pm 1,084$; sessão2: \pm 0,998). A variação dos resultados das equipes foi menor que os resultados individuais, e foi reduzida mais pela experiência $( \pm 0,874$ e $\pm 0,589$ para sessões 1 e 2, respectivamente). Os desvios padrões médios para os resultados individuais e de equipe diminuíram com a experiência em resultados. Independente do treinamento, no entanto, os resultados individuais foram mais variáveis que os resultados das equipes. No estudo de acompanhamento, uma análise detalhada da confiabilidade entre classificadores foi feita a partir de 8 laboratórios diferentes.

\section{Resultados da escala BBB}

Os resultados indicam que a escala BBB é uma medida fácil e sensível da recuperação locomotora que foi concebida para refletir a recuperação progressiva após a contusão do cordão espinhal e fornece uma escala expandida para mostrar os comportamentos nas fases de recuperação inicial, intermediária e avançada. Podendo ser reprodutível com confiança em diferentes laboratórios.

\section{Scale validation}

The effectiveness of the BBB scale was evaluated through the analysis of the relationship among the locomotor results and the injury size, sensitivity and severe different injuries and the change of the results among the categories. In order to validate the new scale, the results of the rats presenting different gravity wounds in two groups were compared. If the scale were valid, it should distinguish the damaged rats with soft and moderate contusions

The relationship between the injury size and the final results in field were analyzed in a sub-group of injured rats. The cords included in the analysis represented all the rats of this study. Some animals were excluded from the anatomical analyzes in function of premature death, loss of tissue, deeper anatomical investigations or deformation of the cord in the injury region.

The change among the classifiers was tested in 6 classifiers presenting a classification experience in field that varied from the minimum to the extensive one before the training with the BBB scale. This change was measured twice: once after the examiners have finished 49 tests in field with the BBB scale and it was repeated after the registers of 118 tests. During each session, animals representing the initial, intermediate and advanced stages of the recovery were tested.

During the tests sessions among classifiers, the individual investigators registered the results with the rats first in an independent way and after they discussed in pairs and defined a consensus about the results. Therefore, each animal received 6 individual marks and 3 group marks.

\section{Reliability among classifiers}

To evaluate the reliability of the classification scale, the results with the same rats elaborated by 6 examiners were compared. The change of classifiers was estimated from the standard deviation of the results presented by the examiners. The change was clearly low, either for the individual modalities or for the groups. The mean change result for the 6 subjects was in the results category limits for each session (session $1: \pm 1,084$; session $2: \pm 0,998)$. The results change of the groups was lower than the individual results and it was diminished by the experience $( \pm 0,874$ and $\pm 0,589$ for sessions 1 and 2 , respectively).

The mean standard deviations for the individual and group results diminished with the experience in results. Despite the training, however, the individual results were more variable than the group results. In the attendance study, a detailed analyzes of reliability among classifiers was performed from 8 different laboratories.

\section{BBB scale results}

The results show that the BBB scale is an easy and sensitive measure of the locomotor recovery that was developed in order to reflect the progressive recovery after the spinal cord contusion. It provides an expanded scale that shows the behavior in initial, intermediate and advanced stages of the recovery. It can be reproduced with confidence in different laboratories.

The relationship between the final performance in field and the quantity of loose tissue was analyzed through the linear regression. Twelve cords in plastic were excluded from the regression analysis due to their extensive degradation. These rats underwent additional anatomical analysis of the detached descending systems. The spinal medulla of an animal from NYU was also excluded due to its shape that was severely distorted when cut providing inaccurate measures of the area. The locomotor results in field for the rats contused by the 
A relação entre o desempenho final de campo, e a quantidade de tecido solto, foi analisado através de regressão linear. Doze cordões colocados em plástico foram excluídos da analise de regressão em virtude de sua degradação extensiva, sendo feito nesses ratos analises anatômicas adicionais dos sistemas descendentes avulsos. A medula espinhal de um animal da NYU foi também excluído em virtude de sua forma que estava severamente destorcida ao ser cortada tornando as medições da área imprecisas. Os resultados locomotores de campo para os ratos contundidos com os Impactores OSU e NYU foram comparados através da analise de variação. Os fatores analisados foram gravidade do ferimento (leve, moderado), membros traseiros (direito, esquerdo) e testes (semanas pósoperatórias) com medições repetidas dos segundos e terceiros fatores. Os resultados locomotores para 3 ratos NYU no grupo leve foram imputados em dois pontos pois os ratos tinham se recuperado a uma condição normal (resultado de 21) e foram sacrificados duas semanas antes que os outros ratos no grupo. A analise pós operatório incluiu um teste para efeito simples quando uma interação importante tinha sido encontrada, e incluía também os testes dos alunos juntamente com correções para os testes múltiplos. A variação entre categorias nos resultados individuais e de duplas foram medidas usando desvio padrão do resultado locomotor que tinha medida feita a partir de vários examinadores.

\section{Método de Tarlov}

Tarlov ${ }^{(17)}$ produziu em 1954 uma compressão aguda e gradual na medula espinhal e calda eqüina em cães.

A experiência foi feita com balões exatamente no meio do espaço epidural da medula espinhal nos níveis de T5-T9 e foi introduzido através de uma pequena laminectomia em T12. A posição dos balões foi checada por Raio-X. Os balões foram inflados em três tamanhos.

O balão tamanho grande quando totalmente cheio tinha aproximadamente o mesmo tamanho do canal medular seguida de paralisia completa em todos os casos (capacidade 1cc). A capacidade do balão de tamanho médio é de0.9cc.o que produziu paralisia completa em $90 \%$ dos cães.

O balão pequeno de capacidade de 0,8 cc. foi inflado em compressão suave até a paralisia completa e perda da sensibilidade.

Para comprimir a calda eqüina, um balão vazio foi introduzido através de um pequena laminectomia entre L7 e S1 e acima da extradural no meio da vértebra de L5. Foi observado que a divisão das raízes dos nervos da calda eqüina produziram paralisia dos membros inferiores, sendo completa nos tornozelos e joelhos mas nem sempre completa na bacia. Somente os balões grandes foram usados para comprimir a calda eqüina porque os demais falharam ao produzir paralisia. O fato é que a lombar é maior que o canal vertebral torácico e que as raízes da calda eqüina são mais resistentes à compressão por lesão medular ; de fato os balões pequenos freqüentemente fracassaram ao produzir paralisia nas patas traseiras.

Os cães foram testados em intervalos durante o dia ; depois destes intervalos foram avaliados semanalmente em razão do restabelecimento funcional

O critério utilizado para o estudo da função motora das patas traseiras foi o seguinte:

0 - nenhum movimento voluntário;

1 - percetível movimento nas articulações;

2 - bons movimentos articulares mas inabilidade para se levantar;

3 - habilidade para se levantar e caminhar;

4 - completa recuperação.
OSU and NYU Impactors were compared through the change analysis.

The analyzed factors were the wound gravity (soft, moderate), posterior members (right, left) and tests (postoperative weeks) with repeated measurements of the second and third factors. The locomotor results for 3 NYU rats in the soft group were imputed in two points as the rats presented a recovery to a normal condition (result of 21) and were killed two weeks before the other rats in the group.

The postoperative analysis included a test to a simple effect when an important interaction was found besides the students tests and the corrections for the multiple tests. The change among categories in individual and pair results was measured by the standard deviation of the locomotor result that was measured by several examiners.

\section{Tarlov's method}

In 1954, Tarlov ${ }^{(17)}$ produced a gradual and acute compression of the spinal medulla and equine tail in dogs.

The experience was made with balloons settled exactly in the middle of the epidural space of the spinal medulla, in the levels T5-T9 introduced through a small laminectomy in T12. The balloons position was verified by X-ray. The balloons were blown in three different sizes.

When it was full, the big balloon was approximately the same size of the medullary canal and produced complete paralysis in all cases (capacity $1 \mathrm{cc}$ ). The capacity of the medium balloon was $0.9 \mathrm{cc}$ and it produced complete paralysis in $90 \%$ of the dogs.

The small balloon capacity was $0.8 \mathrm{cc}$ and it was blown in soft compression until the complete paralysis and loss of sensitiveness.

To compress the equine tail, an empty balloon was introduced between $L 7$ and S1 and over the extradural in the middle of the vertebra of $L 5$ through a small laminectomy. It was observed that the nervous roots division of the equine tail produced paralysis in lower members - complete paralysis in the ankles and knees but not always complete in the pelvic cavity. Only the big balloons were used to compress the equine tail because the others failed in producing paralysis. The fact is that the lumbar is bigger than the thoracic vertebral canal and the roots in the equine tail are more resistant to the compression by medullary injury; in fact, the small balloons frequently failed in producing paralysis in the feet posterior.

The dogs were tested in intervals during the day; after these intervals, they were evaluated weekly because of the functional reestablishment.

The criterion used to study the motor function of the feet posterior was the following:

\section{0 - no volunteer movement}

1 - perceptive movement in articulations

2 - good articular movements but inability to get up

3 - ability to get up and walk

4 - complete recovery

The animals were killed when they were completely recovered or at the moment they had stopped in their recovery course for a long time. Some dogs died before reaching each stage.

\section{Tarlov's scale result}

The functional recovery of a medullary injury by compression in 
Os animais foram sacrificados quando estiveram totalmente restabelecidos ou quando tinham estacionados em seu curso de recuperação por longo tempo. Alguns cachorros morreram antes de atingir cada estágio.

\section{Resultados da escala de Tarlov}

A recuperação funcional de uma lesão medular por compressão em cães depende da magnitude da força de compressão tanto quanto da sua duração.

Embora a recuperação da lesão da medula espinhal possa começar nos primeiros cinco dias após a compressão, é possível que se atrase ao longo dos 30 dias após a lesão da medula e 59 dias depois da compressão da calda eqüina.

A duração da compressão da medula é compatível com a recuperação mais longa dos animais - de uma semana ou mais -o que mostra completa perda da função motora e preservação da sensação dolorosa. Quando a medula espinhal ou a calda eqüina é comprimida, os cães imediatamente tornam-se irrequietos, rosnam e algumas vezes defecam, urinam e tentam morder. Foi observado no entanto que alguns cães mostraram paralisia completa da pata traseira e ainda sentiam formigamento na superfície das patas deste membro. Dez cães mostraram dores fortes depois de completa paralisia dos membros traseiros. Estudos em animais de controle mostraram que o tecido encapsulado causado pelos balões não mudaram a medula espinhal.

Tator em seus estudos, descreveu um novo modelo de lesão medular em ratos através de pinça de aneurisma modificado que produzia uma força de compressão de $180 \mathrm{gr}$ podendo ter o controle na localização, força e tempo de compressão. Porém Khan e Griebel et al. (15) comparou três técnicas de lesão experimental:a)queda de peso , b)compressão com clip de aneurisma e c) compressão extradural com balão e conclui que o fator principal na patogenia da lesão medular pela queda de peso é mecânico ; enquanto que com a utilização da pinça de aneurisma e o balão extradural apresentam fatores mecânicos e vasculares.

Tator et al. ${ }^{(19)}$ realizaram estudos sobre os resultados de recuperação neurológica com pacientes humanos e comparou com os resultados encontrados por Tarlov et al.(18), Wrathall et al.(21) e Basso et al. ${ }^{(2,3)}$. Segundo Tator ${ }^{(19)}$, um dos mais notáveis achados destes estudos experimentais foi a descoberta clinicamente significativa que as funções neurológicas poderiam ocorrer com preservação ou recuperação de somente uma pequena fração dos axônios da região lesada. Foi encontrada uma boa função em testes com plano inclinado em ratos com preservação de $10 \%$ dos axônios, o que corresponde a apenas 400,000

\section{Resultados das analises de Tator}

As recentes descobertas na medula espinhal de mamíferos adultos, das células mães que se proliferam e os recentes métodos para aumentar a regeneração axonal mostra um importante significado das funções neurológicas após lesão no SNC. As lesões na medula espinhal podem causar numerosos efeitos vasculares que podem se dividir em efeitos sistêmicos e locais. Investigações têm mostrado que causas paralelas aos efeitos do sistema vascular e prejuízos mecânicos imediatos à microvascularição da medula seguiu-se de lesões secundárias destes vasos e esta combinação produziu uma isquemia na medula espinhal que poderia progredir.

\section{DISCUSSÃO}

$\mathrm{Na}$ escala motora de Basso et al.(2) todos os testes de reflexos (extensão dos dedos, estímulo doloroso, respostas da pata traseira, dogs depends on the magnitude of the compression force and its length. Although the recovery of the spinal medulla injury can start during the first 5 days after the compression, it is possible that it delays during 30 days after the medullary injury and 59 days after the compression of the equine tail.

The length of the medullary compression is compatible to the longer recovery of the animals - one week or more - what shows a complete loss of motor function and preservation of the pain. When the spinal medulla or the equine tail is compressed, the dogs immediately become irritable, snarl and sometimes defecate, urinate and try to bite.

However, it was observed that some dogs presented complete paralysis of the posterior foot but felt formication on the surface of this member. Ten dogs presented strong pain after the complete paralysis of the posterior members. Studies in control animals showed that the encapsulated tissue caused by the balloons didn't change the spinal medulla.

In his studies, Tator described a new model of medullary injury in rats through the forceps of modified aneurysm that produced a compression force of $180 \mathrm{gr}$. and providing a localization, force and time of compression control.

Therefore Khan and Griebel et al. (15) compared three techniques of experimental injury: 1) weight drop, b) compression by an aneurysm clip and c) extradural compression with balloon and concluded that the main factor for pathogeny of the medullary injury by the weight drop is mechanical; the use of the forceps of aneurysm and the extradural balloon present mechanical and vascular factors.

Tator et al. ${ }^{(19)}$ performed studies on the neurological recovery results with human patients and compared to the results obtained by Tarlov et al. ${ }^{(18)}$, Wrathall et al. ${ }^{(21)}$ and Basso et al. ${ }^{(2,3)}$. According to Tator ${ }^{(19)}$, one of the most notable findings of this experimental study is the clinically significant discovery that the neurological functions can occur with the preservation or recovery of only a small fraction of the axons of the injured region. It was found a good function in skew plain in rats with $10 \%$ of preservation of axons corresponding to only 400,000 .

\section{Tator's analyses results}

The late discoveries on the spinal medulla of adult mammal, of the mother cells that proliferate and the recent methods to increase the axon regeneration show an important significance of the neurological functions after injury in the SNA. The injuries in the spinal medulla can cause innumerous vascular effects that can be divided into systemic and local effects. Investigations have shown that the parallel causes to the vascular system effects and the immediate mechanical damage to the microvascularization of the medulla were followed by secondary injuries of these vessels and this combination produced an ischemia of the spinal medulla that could develop.

\section{DISCUSSION}

In the motor scale of Basso et al.(2) all the reflection tests (extension of toes, painful stimulus, response of foot posterior, clear in extension and response to the animal ventralization) were performed. The conditions of weight and impact force in the injuries of three different levels (soft, intermediate and advanced) could be determined in a reproductive way due to the high level of sensitiveness. The motor findings and histological results performed in dogs in Tarlov ${ }^{(16,17)}$ 's research contributed to the development of safer scales. However, it is not possible to evaluate the injuries levels (light, intermediate and advanced) since only the big balloons were used to compress the equine tail 
retirada em extensão e resposta à ventralização do animal ) foram realizados podendo ser determinada as condições de peso e força de impacto nas lesões dos três diferentes níveis (leve, intermediária e avançada) de forma reprodutível por possuir alto grau de sensibilidade. Os achados motores e resultados histológicos realizados em cães nas pesquisas de Tarlov ${ }^{(16,17)}$ contribuíram para o desenvolvimento de escalas mais seguras porém não se pode avaliar os níveis de lesão (leve, intermediária e avançadas) já que somente os balões grandes foram usados para comprimir a calda eqüina e os demais falharam ao produzir paralisia, analisando de maneira insatisfatória diferentes níveis de lesão. Tator ${ }^{(19)}$ porém descreve um novo modelo experimental realizado em ratos, com compressão por pinça de aneurisma que apesar de se ter controle da localização, força e tempo de compressão não é bem aceito por possuir um alto grau de alteração vascular.

\section{CONCLUSÃO}

Observou-se que através da análise dos dados fornecidos pelas escalas, que o modelo experimental de avaliação motora mais aceito é o de Basso et al. ${ }^{(2)}$, pois quantifica de maneira satisfatória a recuperação das funções motoras nas lesões medulares sem desvios motivados pela metodologia de observação.

Os outros métodos estudados, mostraram limitações técnicas e respostas fisiológicas que interferiram negativamente na obtenção de resultados seguros e reprodutíveis em diferentes laboratórios. while the others failed in producing paralysis, analyzing unsatisfactorily the different levels of the injury.

Tator $^{(19)}$ describes a new experimental model performed in rats with compression by forceps of aneurysm that in spite of having the localization, the force and the time of compression it is not well accepted due to it presents a high level of vascular alteration.

\section{CONCLUSION}

Through the provided data analysis it was observed that the experimental model of motor evaluation more accepted is the Basso et al. (2)'s one therefore it quantifies satisfactorily the recovery of the motor functions in medullary injuries without deviations caused by the observation methodology.

The other studied methods showed technical limitations and physiological responses that interfered negatively in obtaining safe reproductive results in different laboratories.

\section{REFERÊNCIAS BIBLIOGRÁFICAS}

1.Allen AR. Surgery of experimental lesion of spinal cord due to impact. An experimental study. JAMA 57:878-880,1911.

2.Basso DM, Beattie MS, Bresnahan JC. A sensitive and realiable locomotor rating scale for open field testing in rats. J Neurotrauma, 12:1-21, 1995.

3.Basso DM, Beattie MS, Bresnahan JC. Graded histological and locomotor outcomes after spinal cord contusion using NYU weight-drop device versus transection. Exp Neurol 139:244-256,1996.

4. DeLa Torre J. Spinal Cord Injury models. Prog Neurobiol 22:289-344, 1984

5. Dohamann GJ, Wagner FC, Bucy PC. The microvasculature in transitory traumatic paraplegia. An electron microscopic study in the monkey. J Neurosurg 35:263-271, 1971

6. Dohamann GL. Experimental spinal cord trauma: a historical review. Arch Neurol 27:468-473, 1972.

7. Doharmann GJ, Panjabi MM. "Standardized" spinal cord trauma: biomechanical parameters and lesion volume. Surg Neurol 6:263-267, 1976.

8. Doharmann GJ, Panjabi MM, Wagner FC. Na apparatus for quantitative experimental spinal cord trauma. Surg Neurol 5:315-318, 1976

9. Doharmann GJ, Panjabi MM, Banks D. Biomechanics of experimental spinal cord trauma. J Neurosurg 48:993-1001, 1978.

10. Ducker TB, Kindt GW, Kempe LG. Pathologics findings in acute experimental spinal cord trauma. J Neurosug 35:700-708, 1971.

11. Fehlings MG. Tator $\mathrm{CH}$. The relationships among the severity of spinal cord injury, residual neurological function, axon counts, and counts of retrogradely labelled neurons after experimental spinal cord injury. Exp Neurol 132:220$228,1995$.

12. Ford RW. A reproducible spinal cord injury model in the cat .J Neurosurg 59:268-275,1983
13. Griffiths IR, McCulloch MC. Nerve fibers in spinal cord impact injuries. Part1. Changes in the myelin sheath during the initial five weeks. J Neurol Sci 58:335349, 1983.

14. Hall ED, Yonkers PA, Horan KL. Correlation between attenuation of postraumatic spinal cord ischemia and preservation of tissue vitamin $E$ by 21 aminosteroid U774006F: evidence for an in vivo antioxidant mechanism. J Neurotrauma 6:169-176, 1989.

15. Khan, $\mathrm{M}$;Griebel, R. Acute spinal cord injury in the rat: comparasion of three experimental techniques. Can.J. Neurol.Sci., v.10.p.161-5,1983.

16. Noble JR, Wrathall JR. Correlative analyses of lesion development and functional status after graded spinal cord contusive injuries in the rat. Exp Neurol 103:34-40,1989.

17. Tarlov IM. Spinal cord compression studies: III.Time limits for recovery after gradual compression in dogs. AMA Arch Neurol Psychiatry 71:588-597,1954

18. Tarlov IM, Klinger H, Vitale S. Spinal cord compression studies: I. Experimental techniques to produce acute and gradual compression. AMA Arch Neuro Psychiatr 70:813-818,1953.

19. Tator $\mathrm{CH}$, Koyanagi I. Vascular mechanisms in the pathophysiology of human spinal cord injury. J Neurosurg 86:483-492,1997.

20. Tator $\mathrm{CH}$. Spine-spinal cord relationship in spinal cord trauma. Clin Neurosurg 30:479-494,1983.

21. Wrathall JR, Teng YD, Choiniere D. Amelioraton of functional deficits from spinal cord trauma with systemically administered NBQX, an antagonist of non-Nmethyl-D-aspartate receptors. Exp Neurol 137:119-126,1996.

22. Wrathall JR, Pettegrew, R.K.,Harvey, F. Spinal Cord Contusion in the rat: Production of graded, reproducible, injury groups. Exp.Neurol.,v.88, p.10822,1985 . 